\title{
Non-opioid medications for the relief of chronic breathlessness: current evidence
}

\section{Carlo Barbetta, David C Currow \& Miriam J Johnson}

To cite this article: Carlo Barbetta, David C Currow \& Miriam J Johnson (2017): Non-opioid medications for the relief of chronic breathlessness: current evidence, Expert Review of Respiratory Medicine, DOI: 10.1080/17476348.2017.1305896

To link to this article: http://dx.doi.org/10.1080/17476348.2017.1305896

Accepted author version posted online: 10 Mar 2017.

Submit your article to this journal ¿

山ll Article views: 4

Q View related articles $\asymp$

View Crossmark data $\asymp$ 
Publisher: Taylor \& Francis

Journal: Expert Review of Respiratory Medicine

DOI: $10.1080 / 17476348.2017 .1305896$

\section{REVIEW}

Title

Non-opioid medications for the relief of chronic breathlessness: current evidence

\section{Authors}

Carlo Barbetta, M.D. - Respiratory Unit, AAS5 Friuli Occidentale, S. Maria degli Angeli Hospital, Pordenone, Italy

David C Currow, BMed, MPH, PhD, FRACP, FAHMS, University of Technology, Sydney Australia; Wolfson Palliative Care Research Centre, Hull York Medical School, The University of Hull, Hull, East Yorkshire, United Kingdom

Miriam J Johnson, MD, FRCP, MRCP, MBChB(hons) - Wolfson Palliative Care Research Centre, Hull York Medical School, The University of Hull, Hull, East Yorkshire, United Kingdom

\section{Corresponding author:}

Miriam J Johnson MD, FRCP, MRCP, MBChB(hons)

miriam.johnson@hyms.ac.uk

Hull York Medical School

Hertford Building, University of Hull, Hull, HU6 7RX 


\section{Abstract}

Introduction: To evaluate systematically randomised clinical trials investigating non-opioid medications for the management and treatment of chronic breathlessness.

Areas Covered: The evidence for the role of benzodiazepines, anxiolytics, selective serotonin re-uptake inhibitors (SSRIs), tricyclic antidepressants, antihistamines, cannabinoids, nebulized furosemide and herbalbased treatments were critically reviewed. Search of the Clinical Trials Registry (Clinicaltrial.gov) identified ongoing studies expected to generate new data in the near future in several classes of non-opioid medications for their net effect on chronic breathlessness.

Expert Commentary: Morphine still has the best levels of evidence for the symptomatic treatment of chronic breathlessness. Non-opioid treatments for chronic breathlessness are less studied than morphine and morphine-related medications although evidence is emerging in relation to some options. Currently, there is insufficient evidence to recommend non-opioids in the routine treatment of chronic breathlessness. There is a need to find agents, new as well as re-purposed, that can be used as alternative therapies to opioids for chronic breathlessness for people who are unable to tolerate morphine.

Key words: breathlessness; dyspnoea; anxiolytic; anti-depressant; nebulized furosemide 


\subsection{INTRODUCTION}

Chronic breathlessness is a core issue for all physician and other health professionals involved in the care of people with a variety of advanced medical conditions. Despite optimal treatment of the underlying pathologies, the multidimensional experience ${ }^{1}$ of distressing chronic breathlessness remains a major problem for patients, their family caregivers and clinicians, often leaving all feeling helpless.

Neuroimaging studies have shown the central pathways involved in response to breathlessness include several limbic, paralimbic and cerebellar loci. ${ }^{2345} \mathrm{This}$, along with a growing understanding of the role of endogenous opioids ${ }^{67}$ and serotonin ${ }^{8}$ in breathing, and the relationship between breathlessness and anxiety and depression ${ }^{910}$, has led to calls to find ways to modulate central neural activity in relation to breathlessness and thus alleviate the unpleasantness, intensity, and emotional and functional responses to breathlessness. ${ }^{111213} \mathrm{~A}$ range of potential drug intervention candidates aiming to modulate central perception have been investigated. This systematic review summarises the evidence so far and discusses the implications for current clinical practice, and for future research.

\subsection{IDENTIFICATION OF LITERATURE}

To identify potential studies we searched MEDLINE, EMBASE, Google Scholar for randomised controlled trials investigating the role of potential non-opioid medications for the relief of chronic breathlessness due to medical conditions. We included studies where chronic breathlessness due to medical conditions was measured as a primary or secondary outcome. Clinical trials and relevant retrospective and prospective observational studies (especially if trials were few or lacking) exploring the role of a specific drug-classes were included. The reference lists of studies identified and relevant reviews were hand-searched. We also searched registers of clinical trials for further ongoing or unpublished studies, up to November 2016.

List of terms and words used for the systematic search and review of published clinical trials: "dyspnea" , "dyspnoea", "breathlessness", "symptom", "drug", "agent", "benzodiazepines", "anxiolytic", "antihistamines", "SSRI", "selective serotonin reuptake inhibitor", "tricyclic antidepressant", "anti-histamine", "nebulized furosemide", "inhaled furosemide", "herbs", "herbal”, "cannabis", "tetrahydrocannabinol". Steroids were not included as they most likely mediate any effect on breathlessness indirectly through their anti-inflammatory actions on the underlying disease process rather than directly modifying the perception (e.g. asthma, peritumour oedema in lymphangitis carcinomatosis). Antihistamines were included because they also have central sedative effects.

One researcher (CB) screened titles, abstracts, retrieved papers and extracted data. Uncertainty regarding inclusion was resolved by discussion with MJ.

\subsection{FINDINGS}

The findings are presented by drug class. 


\subsection{Anxiolytics}

\subsubsection{Benzodiazepines}

Anxiolytics, such as benzodiazepines, are commonly used to help to reduce chronic breathlessness in palliative care settings. The need for robust placebo-controlled safety data regarding benzodiazepines is illustrated by recent observational studies. A population registry-based, longitudinal, consecutive cohort study on 2249 people with severe COPD on long term oxygen found that benzodiazepines and low dose oral morphine ( $\geq 30 \mathrm{mg}$ morphine equivalent daily dose) were not associated with increased hospital admission, but benzodiazepines ( but not low dose morphine) were associated with increased mortality in a dose-related manner. ${ }^{14} \mathrm{~A}$ risk of increased respiratory adverse events due to use of benzodiazepines in people with COPD was also highlighted by Vozoris et al in a large cohort study. In benzodiazepine-naive people with COPD a new prescription of benzodiazepines was linked to an increased rate of outpatient respiratory exacerbations (RR $1.45 \mathrm{Cl} 1.36-1.54$ ) compared to non-users. ${ }^{15}$

A pilot phase I open label trial evaluated the role of oral clonazepam 0.5 nocte and $10 \mathrm{mg}$ oral sustained release morphine, administered for at least 4 days, in 11 people with COPD and chronic breathlessness (modified Medical Research Council dyspnoea scale $[\mathrm{mMRC}] \geq 2$ ). (Table 1) Despite the study's limitations, a positive effect of clonazepam in reducing breathlessness by $15 \%$ over baseline was found, indicating the need for further study. ${ }^{16} \mathrm{~A}$ retrospective analysis of 115 clinical records in a population of people with cancer, heart failure or COPD suggested that patients receiving opioids and benzodiazepines showed greater improvement of breathlessness compared to those receiving only opioids or benzodiazepines. ${ }^{17}$ Midazolam was also used in a palliative sedation protocol ${ }^{18}$ in 4 people in the last hours or days of life with cancer and severe breathlessness, and was reported to be effective.

The safety of lorazepam $1 \mathrm{mg}$ sublingually in addition to opioids was evaluated in a prospective nonrandomised study of 26 patients admitted to a palliative care unit with chronic breathlessness and anxiety. Lorazepam combined with opioids appeared to be safe and effective in relieving breathlessness and anxiety in the palliative care setting since no clinically important variations of $\mathrm{SpO}_{2}$ and $\mathrm{pCO}_{2}$ were recorded. Breathlessness and anxiety were recorded and monitored with a 0-10 numeric rating scale (NRS) however; sedated patients might not have been able to distinguish between the two sensations. This might explain the similar scores and the very strong relationship observed between chronic breathlessness and anxiety $(r=0.952, p<0.0001) .19$

\subsubsection{Randomised controlled trials}

A recently updated Cochrane review ${ }^{20}$ of a range of benzodiazepines (diazepam, midazolam, alprazolam, lorazepam) showed no evidence of a net benefit on chronic breathlessness in people with cancer or COPD when compared to placebo. The review concluded that any use of benzodiazepines for chronic breathlessness should be as a second or third-line treatment within a carefully monitored individual therapeutic trial. Route of administration was not significant in sensitivity analysis. The pressing need is for adequately powered, randomised controlled trials in order to inform clinicians in everyday practice rather than further phase II studies or case series.

\subsubsection{Buspirone}


Buspirone, an azapirone which does not suppress respiration used in the management of generalized anxiety disorders, has been suggested as a potential modulator of chronic breathlessness. Small, underpowered trials have given mixed results, ${ }^{21}{ }^{22}$ however, a recent phase III clinical trial in people with cancer and chronic breathlessness showed no improvement in breathlessness. ${ }^{23}$ This large study showed no sign of benefit and whether it should be repeated in patients other than those with cancer remains open to discussion.

\subsubsection{Ondansetron}

Ondansetron is a serotonin antagonist, commonly used to treat chemotherapy-induced emesis. It is also considered to have a possible anxiolytic and anti-psychotic effect. ${ }^{2425} 26$ Exploratory work investigated its potential role as a modulator of chronic breathlessness working on the insular cortex in a small $R C T(n=10)$, but showed no benefit in healthy volunteers with experimentally induced acute breathlessness. ${ }^{27} \mathrm{~A}$ study of inhaled ondansetron ( $8 \mathrm{mg}$ ) compared to inhaled $0.9 \%$ saline in healthy subjects in whom acute breathlessness was induced by thoracic constriction and exercise [NCT01851993] is ongoing. It is not known how such findings will apply to the context chronic breathlessness.

\subsection{Antidepressants}

\subsubsection{The epidemiology of chronic breathlessness and depression}

Antidepressants such as selective serotonin re-uptake inhibitors (SSRIs) and tricyclic antidepressants have been studied for their potential role in reducing chronic breathlessness. ${ }^{28} \mathrm{~A}$ pathophysiological link between respiratory and psychiatric symptoms could be found at the level of serotonergic system and its effect on the modulation of central respiratory control and sensitivity to carbon dioxide. A cross sectional study of 836 people with COPD estimated the prevalence of depression and related symptoms. ${ }^{29}$ About three quarters of this large unselected population of COPD patients had depression; this was moderate or severe in half (51.5\%). Depression was associated with a poorer quality of life (QoL), increased rates of exacerbations and higher prevalence of comorbidities. Breathlessness prevalence was associated significantly in people with COPD and depression. Another cross-sectional observational study of 54 people with COPD explored the relationship between anxiety, depression, breathlessness and thoraco-abdominal mechanics at rest and/or during exercise. Anxiety and depression were associated with poorer clinical disease control and depressive symptoms were associated with breathlessness, independent of breathing pattern and thoraco-abdominal mechanics. ${ }^{30}$

\subsubsection{Randomised controlled trials}

Exploratory studies of people with COPD are limited by the small sample sizes and underlying methodologies used. ${ }^{191-36}$ These provide preliminary support to further explore a role for these drugs in reducing anxiety and chronic breathlessness, and improving quality of life. However, a Cochrane Review in 2011 failed to demonstrate conclusive evidence for SSRI and tricyclic antidepressants in managing breathlessness, despite improvement in anxiety, quality of life and exercise tolerance with paroxetine 20 $\mathrm{mg} /$ daily. ${ }^{37} \mathrm{~A}$ randomised trial of 138 patients with COPD and major depression compared a Personal Intervention (PID-COPD) against usual care over 28 weeks; findings showed that PID-COPD led to an interacting spiral of improvement, improved adherence with antidepressant treatment and COPD rehabilitation, and reduced breathlessness-related disability. However, in this complex intervention there 
were different factors and drugs used and evaluation of particular sub-classes of antidepressants was not possible. ${ }^{38}$ An RCT of people with COPD and depression found that those allocated to fluoxetine $25 \mathrm{mg} /$ daily in addition to usual care compared with usual care only had improvement in breathlessness scale scores, oxygenation and spirometry. ${ }^{39}$

Dale et al. (2012) enrolled 36 people with cancer in a cross over, double blind randomised trial to evaluate mirtazapine (15mg vs $30 \mathrm{mg}$ ), showing improvement of many cancer related symptoms and QoL. ${ }^{40}$ A phase II trial is ongoing to test the feasibility of a phase III trial to evaluate mirtazapine for the management of chronic breathlessness due to a variety of optimally treated medical conditions. [Eudract number $2015-$ 004064-11]

Phase III RCTs are required to give definitive evidence of these agents for the treatment of breathlessness; one is due to report early 2017 (ACTRN12610000464066; sertraline for chronic breathlessness). ${ }^{41}$ A safety trial in people with COPD undergoing pulmonary rehabilitation is underway ([NCT02813447]; primary outcomes of breathlessness scores, quality of life and exercise tolerance measures will be primary outcomes.

\subsection{Antihistamines}

Antihistamine agents (anti-H1) have been investigated alone or in association with benzodiazepines or morphine to reduce breathlessness. These drugs have anti-muscarinic and anti-serotonergic activity leading to sedative and antipsychotics effects. ${ }^{42}$ Promethazine has been investigated in different settings to evaluate a potential role in breathlessness management and as an opioid-sparing treatment.

Six healthy volunteers took promethazine $25 \mathrm{mg}$ orally before a treadmill test and reported reduced effortinduced acute breathlessness (VAS) although this did not reach statistical significance. ${ }^{43}$ The finding was not confirmed in another study of 12 healthy subjects. ${ }^{44}$ In this study, half also received chlorpromazine; these participants had a statistically significant improvement in acute breathlessness scores (mean relative reduction $19.3 \%$ ), with no evidence of respiratory depression. The application of these findings to the clinical setting of chronic breathlessness has not been studied at this time.

An evaluation of the effect of $125 \mathrm{mg}$ promethazine daily for two weeks in 15 men with COPD ("pink puffer" phenotype) showed a reduction in breathlessness scores and improved exercise tolerance. ${ }^{45}$ However, promethazine $100 \mathrm{mg}$ daily given to 11 people with COPD showed no improvement in breathlessness at 1 month. ${ }^{46}$ An evaluation of $25 \mathrm{mg}$ promethazine together with morphine $30 \mathrm{mg}$ administered before exercise in 7 men with COPD gave improved exercise tolerance and increased maximum minute ventilation, but showed no differences in perceived breathlessness (Borg scale). ${ }^{47}$ These findings cannot be applied to clinical practice at this time.

\subsection{Cannabinoids}

Cannabis and cannabis-related molecules have been investigated to evaluate their potential role in the treatment of several symptoms in a wide sub-set of patients. A recent meta-analysis, conducted according to Cochrane criteria, highlighted both the potential benefit and appreciable risks of these drugs. ${ }^{48}$

Cannabinoids have been studied by Pickering et al. as a potential treatment for breathlessness in a small ( 9 
patients, 4 with moderate COPD) RCT comparing the effect of cannabis-based medicinal extract with placebo in reducing acutely induced breathlessness. Results showed no changes on VAS measurements although COPD patients used fewer "breathlessness" descriptors. Participants reported adverse events (intoxication and reversible cardiac dysrhythmias). ${ }^{49}$ Therefore current evidence does not support the use of acutely administered cannabinoids for breathlessness.

\subsection{Nebulized furosemide}

Animal models suggest a potential role for furosemide in changing local chloride ion channels and its negative effect on c-fibers receptor and vagal irritant receptors, and an associated positive effect on alveolar stretch receptors. ${ }^{50}$ Nebulised inhaled furosemide (NIF) has been tested in acute breathlessness induced in healthy volunteers and in people with acute asthma ${ }^{51}, \operatorname{COPD}^{52534}$, heart failure ${ }^{55}$ and lung cancer. $^{56-59}$

\subsubsection{NIF in experimental settings}

Three studies tested NIF $40 \mathrm{mg}$ compared to $0.9 \%$ saline in 32 subjects (respectively $n=12, n=10, n=10$ ) evaluating its role in reducing breathlessness and air hunger during experimental conditions (loaded breathing test, breath holding, $\mathrm{CO}_{2}$ chemosensitivity measured by the steady-state and rebreathing methods, hypercapnia during constrained ventilation) in double blind randomised cross over trials. ${ }^{606162}$ Findings showed a reduction in breathlessness which was not correlated with the ventilator drive of $\mathrm{CO}_{2}$. NIF $40 \mathrm{mg}, 80 \mathrm{mg}$ or normal saline in 9 healthy subjects found no benefit from NIF in alleviating respiratory effort during flow limited exercise. ${ }^{63}$

\subsubsection{NIF and COPD}

NIF $40 \mathrm{mg}$ was compared to $0.9 \%$ saline in two studies in $19^{52}$ and $20^{53}$ people with COPD respectively undergoing exercise tests (incremental exercise, symptom limited exercise) to induce breathlessness. Both trials showed a reduction in breathlessness intensity, increased exercise endurance and optimisation of lung volumes, with an improvement in $\mathrm{SpO}_{2}$ levels rather than a diuretic effect. NIF $40 \mathrm{mg}$ compared to $0.9 \%$ saline in 100 people with exacerbations of COPD admitted to an emergency department showed that those allocated to NIF had a statistically significant improvement in Borg scores, spirometry, blood gases, heart and respiratory rate, and blood pressure. All subjects also inhaled salbutamol and ipratropium, and received intravenous hydrocortisone. ${ }^{58}$ These data suggest that a trial of NIF $40 \mathrm{mg}$ to reduce chronic breathlessness in COPD exacerbations is safe, while further work is needed to evaluate its role in relieving chronic breathlessness. Cardiovascular co-morbidities are frequent in people with moderate or severe COPD. None of these studies noted this comorbidity so work is needed to evaluate the effect of NIF on chronic breathlessness as a result of cardiac failure. Recently NIF was compared to normal saline in people with stable advanced heart failure (32 patients) undergoing right heart catheterisation. No difference were observed in haemodynamic parameters in the one hour after administration of the drug, but a diuretic effect was seen in those allocated to NIF. ${ }^{59}$ Breathlessness was not measured in this study. Further research is warranted.

\subsubsection{NIF and cancer}


NIF has been tested to reduce chronic breathlessness in people with lung cancer. Studies are small and have found mixed results. ${ }^{60616263}$

All these studies have used nebulised saline as the control arm and used either jet or ultra-sonic nebulizers. It is important to note that nebulised saline, administered via an efficient nebulizer, improved breathlessness scores and sputum clearance in people with COPD and therefore may have a role in its own right in the relief of breathlessness, and makes the interpretation of studies of nebulised agents more challenging. ${ }^{64}$

Currently two clinical trials of nebulised furosemide to reduce chronic breathlessness are registered as open. NCT01851980 will investigate the role of NIF on Physical Activity-Related Breathlessness in a human model of exercise-induced breathlessness (primary outcome: intensity of breathlessness on a Borg 0-10 scale); and NCT02524054 aims to evaluate NIF in patients with refractory breathlessness (primary outcome: intensity of breathlessness on a VAS). Results are expected during 2017.

\subsection{Herbal based treatments}

Herbal based treatments such as Bu-Fei Jian-Pi granules, Bu-Fei Yi-Shen granules and Yi-Qi Zi-Shen granules in addition to standard GOLD guideline COPD therapy have shown reduction in breathlessness in an openlabel RCT of 352 people with COPD. ${ }^{66}$ Further, a secondary sub-set analysis on 136 patients older than 65 years old, saw the same result. ${ }^{65}$ These different kinds of granules have been administered to specific patient clusters, according to the traditional Chinese medicine. Further research based on designed placebo controlled RCT in breathlessness patients, alongside systematic documentation of toxicities is therefore advised.

\subsection{CONCLUSIONS}

Extended release morphine remains the most studied symptomatic treatment for chronic breathlessness. There is an urgent continuing need to explore other therapeutic interventions. Such studies are, in part, based on the emerging knowledge of the central pathways and receptors involved in the perception and modulation of the perception of chronic breathlessness.

This review summarises the current evidence for currently available agents with regard to potential repurposing for the management of breathlessness. None have more than preliminary evidence to support their use and some have evidence to show they have no role. Further work is required for those with potential. It is not possible currently to make recommendations with regard to which drug for which person. There is also a need to identify new agents specifically developed to interact with the perception of breathlessness safely.

\subsection{EXPERT COMMENTARY}

Chronic breathlessness due to medical conditions has a serious impact on the daily experience of those who live with it, their family and friends and the health and social care professionals. ${ }^{6768} \mathrm{It}$ is more strongly associated with survival than surrogate markers of lung function, ${ }^{69}$ and people with chronic breathlessness 
are more likely to have poor quality of life ${ }^{70}$ anxiety and depression, ${ }^{71}$ and increased health service utilisation especially emergency services. ${ }^{72}$ Breathlessness, in a traditional medical model, views the symptom largely as a diagnostic signpost, with the focus of management thereafter being interventions for the causative medical condition. However, despite optimum disease-directed treatment, breathlessness will persist for many, especially as the disease advances. There are evidence-based treatments for chronic breathlessness itself, particularly based on non-pharmacological interventions which remain the bedrock of breathlessness management. However, they are not implemented systematically into clinical practice partly due to lack of clinician education and partly due to lack of resources. Further, patients may persist with troublesome chronic breathlessness despite such measures, in which case, pharmacological approaches may be of use. Recourse to pharmacological measures may be needed sooner in people with a rapid decline, than those with a more stable trajectory. The evidence base for pharmacological interventions is growing, but is strongest for oral low-dose morphine. However, not all patients will tolerate morphine and other pharmacological approaches are needed.

There are a number of published clinical trials of mainly preliminary evaluation of a range of medications which have a biologically plausible rationale for re-purposing for breathlessness management. These include anxiolyotics, antidepressants, antihistamines, cannabinoids and nebulised furosemide. Only one adequately powered trial of an anxiolytic has been reported so far (buspirone vs placebo in people with breathlessness due to cancer) which demonstrated no benefit. This trial, however, shows the importance of trials which recruit to their a priori sample size as previous phase II work had indicated benefit. A phase III trial for sertraline is due to report in 2017. However, much of the other work has failed to show promise, or has been inconclusive. The exception perhaps is nebulised medication such as furosemide and normal saline where further study seems to be warranted. The ultimate goal in this field is to be able to offer patients tailored pharmacological interventions to benefit chronic breathlessness thereby improving functional ability, quality of life and levels of independence.

Future work requires well designed trials with adequate power to test the effectiveness of both repurposed drugs and also newly developed compounds. Therefore greater understanding of the pathophysiological pathways of the genesis and perception of chronic breathlessness itself is needed to inform potential targets for new interventions. A better understanding of whether benefits seen for breathlessness in one medical condition are replicated in another. For example, is the improvement in breathlessness with nebulised normal saline in people with COPD mediated through improved mucous clearance and if so, does this mean that the benefit would not be seen in patients with interstitial lung fibrosis? Another challenge is the need to understand how health service provision for such patients should be best provided in order to implement interventions directed at both the underlying disease and the ongoing symptom in an integrated manner.

Current developing areas of research include work to understand the pathways of central perception of chronic breathlessness, the effectiveness and implementation of complex interventions for breathlessness in different settings, and systematic testing of medications to improve this previously neglected symptom. 


\subsection{FIVE-YEAR VIEW}

With regard to non-opioid medication for the management of chronic breathlessness, we anticipate that in five years, research with selective serotonin reuptake inhibitors (SSRI) and serontonin and noradrenaline inhibitors (SNRI) will be defined for their net effect on chronic breathlessness. We should have a clearer understanding of the role of nebulised furosemide. We hope that multi-disciplinary breathlessness assessment and management as a specific focus alongside ongoing optimisation of the underlying cause(s) will become a routine part of clinical practice.

\subsection{KEY ISSUES}

- Morphine has the best levels of evidence for the symptomatic treatment of chronic breathlessness.

- Non-opioid treatments for chronic breathlessness are less studied than morphine and morphinerelated medications although evidence is emerging in relation to some options. In particular there is evidence that buspirone is ineffective in people with cancer and nebulized normal saline is helpful in people with COPD.

- Currently, there is insufficient evidence to recommend non-opioids in the routine treatment of chronic breathlessness. Results from a phase III trial of sertraline vs placebo in people with chronic breathlessness due to a variety of causes will report in 2017.

- There is a need to find agents, new as well as re-purposed, that can be used as alternative therapies to opioids for chronic breathlessness for people who are unable to tolerate morphine.

\section{Funding}

This paper was not funded.

\section{Declaration of Interest}

The authors have no relevant affiliations or financial involvement with any organization or entity with a financial interest in or financial conflict with the subject matter or materials discussed in the manuscript. This includes employment, consultancies, honoraria, stock ownership or options, expert testimony, grants or patents received or pending, or royalties. 


\subsection{REFERENCES}

Papers of special note have been annotated as:

* Of interest

** Of considerable interest

1 Bausewein , Currow DC, Johnson MJ Palliative care in Respiratory Medicine ERS Monograph 2016 doi: 10.1183/2312508X.erm7316

** This brings together current knowledge about palliative care in respiratory medicine and includes epidemiology through to patient and carer experience to symptom management. A summary of this paper appears in the chapter on breathlessness management.

2 Peiffer C, Poline JB, Thivard L, Aubier M, Samson Y Neural Substrates for the Perception of Acutely Induced Dyspnea Am J Respir Crit Care Med 2001 Vol 163. pp 951-957

3 Evans KC, Banzett RB, Adams L, McKay L, Frackowiak RSJ, Corfield DR BOLD fMRI Identifies Limbic, Paralimbic, and Cerebellar Activation During Air Hunger J Neurophysiol 2002 88: 1500-1511

4 VonLeupoldt A, Sommer T, Kegat S, Baumann HJ, Klose H, Dahme B, Buchel C The Unpleasantness of Perceived Dyspnea Is Processed in the Anterior Insula and Amygdala Am J Respir Crit Care Med 2008 Vol 177. pp 1026-1032

5 Johnson MJ, Simpson MIJ, Currow DC, Millman RE, Hart SP, Green G Magnetoencephalography to investigate central perception of exercise-induced breathlessness in people with chronic lung disease: a feasibility pilot BMJ Open 2015; 5:e007535. doi:10.1136/bmjopen-2014- 007535

6 Mahler DA, Murray JA, Waterman LA, Ward J, Kraemer WJ, Zhang X, Baird JC: Endogenous opioids modify dyspnoea during treadmill exercise in patients with COPD. Eur Respir J 2009;33(4):771-777.

7 Mahler DA, Murray JA, Waterman LA, Ward J, Kraemer WJ, Zhang X, Baird JC: Endogenous opioids modify dyspnoea during treadmill exercise in patients with COPD. Eur Respir J 2009;33(4):771-777.

8 Feldman JL, Mitchell GS, Nattie EE: Breathing: rhythmicity, plasticity, chemosensitivity Annu Rev Neurosci 2003; 26:239-266.

* This paper provides a fascinating rationale for the role of serotonin in breathlessness

9 Johnson MJ, Bland JM, Gahbauer EA, Ekstrom M, Sinnarajah A, Gill TM, Currow DC: Breathlessness in Elderly Adults During the Last Year of Life Sufficient to Restrict Activity: Prevalence, Pattern, and Associated Factors. J Am Geriatr Soc 2016; 64(1):73-80,

10 Neuman A, Gunnbjornsdottir M, Tunsater A, Nystrom L, Franklin KA, Norrman E, Janson C: Dyspnea in relation to symptoms of anxiety and depression: A prospective population study. Respir Med 2006; 100(10):1843-1849.

11 Currow DC, Abernethy AP, Allcroft P, Banzett RB, Bausewein C, Booth S, Carrieri Kohlman V, Davidson P, Disler R, Donesky DA, Dudgeon D, Ekstrom M, Farquhar M, Higginson I, Janssen D, Jensen D, Jolley C, Krajnik M, Laveneziana P, McDonald C, Maddocks M, Morelot-Panzini C, Moxham J, Mularski RA, Noble S, O'Donnell D, Parshall MB, Pattinson K, Phillips J, Ross J, Schwartzstein RM, Similowski T, Simon ST, Smith T, Wells A, Yates P, Yorke J, Johnson MJ The need to research refractory breathlessness Eur Respir J 2016; 47: 342-343.

12 Currow DC, Johnson MJ. Distilling the essence of breathlessness - the first vital symptom. Eur Respir J 2015; 45: 1526 - 1528 | DOI: 10.1183/09031936.00030115

13 Johnson MJ, Currow DC. Chronic refractory breathlessness is a distinct clinical syndrome Curr Opin Support Palliat Care. 2015 Sep;9(3):203-5. 
14 Ekström MP, Bornefalk-Hermansson A, Abernethy AP, Currow DC Safety of benzodiazepines and opioids in very severe respiratory disease: national prospective study BMJ 2014; 348:g445

** This registry based study of people with advanced COPD showed no association with hospital admission or death in those taking $30 \mathrm{mg}$ per day morphine or less.

15 Vozoris NT, Fischer HD, Wang X, Stephenson AL, Gershon AS, Gruneir A, Austin PC, Anderson GM, Bell CM, Gill SS, Rochon PA Benzodiazepine drug use and adverse respiratory outcomes among older adults with COPD. Eur Respir J. 2014 Aug;44(2):332-40. doi: 10.1183/09031936.00008014. Epub 2014 Apr 17.

16 Allcroft P, Margitanovic V, Greene A, Agar MR, Clark K, Abernethy AP, Currow DC The role of benzodiazepines in breathlessness: a single site, open label pilot of sustained release morphine together with clonazepam. J Palliat Med. 2013 Jul;16(7):7414.

17 Gomutbutra P, O’Riordan DL, Pantilat SZ Management of Moderate-to-Severe Dyspnea in Hospitalized Patients Receiving Palliative Care J Pain Symptom Manage 2013; 45:885e891

18 Mercadante S, Porzio G, Valle A, Aielli F, Casuccio A Palliative sedation in patients with advanced cancer followed at Home: a prospective study J Pain Symptom Manage 2014; 47:860-866

19 Clemens KE, Klaschik E Dyspnoea associated with anxiety-symptomatic therapy with opioids in combination with lorazepam and its effect on ventilation in palliative care patients Support Care Cancer 2011; 19:2027-2033

20 Simon ST,Higginson IJ, Booth S, Harding R,Weingärtner V, Bausewein C. Benzodiazepines for the relief of breathlessness in advanced malignant and non-malignant diseases in adults. Cochrane Database of Systematic Reviews 2016, Issue 10. Art.No.:CD007354. DOI: 10.1002/14651858.CD007354.pub3.

** This review presents the lack of evidence for benzodiazepines for the benefit of breathlessness

21 Argyropoulou P, Patakas D, Koukou A, Vasiliadis P, Georgopoulos D. Buspirone effect on breathlessness and exercise performance in patients with chronic obstructive pulmonary disease. Respiration. 1993; 60(4):216-20.

22 Singh NP, Despars JA, Stansbury DW, Avalos K, Light RW Effects of buspirone on anxiety levels and exercise tolerance in patients with chronic airflow obstruction and mild anxiety. Chest 1993; 103(3):800-804

23 Peoples AR, Bushunow PW, Garland SN, Heckler CE, Roscoe JA, Peppone LL, Dudgeon DJ, Kirshner JJ, Banerjee TK, Hopkins JO, Dakhil SR, Flannery MA, Morrow GR Buspirone for management of dyspnea in cancer patients receiving chemotherapy: a randomised placebo-controlled URCC CCOP study Support Care Cancer 2016 Mar;24(3):1339-47 DOI $10.1007 /$ s00520-015-2903-6

** Phase III trial shows no benefit of buspirone over placebo showing the need for placebo controlled trials of repurposed drugs.

24 Blackwell CP, Harding SM. The clinical pharmacology of ondansetron. Eur J Cancer Clin Oncol 1989;25(Suppl 1):214.

25 Terkawi AS, Mavridis D, Flood P, Wetterslev J, Terkawi RS, Bin Abdulhak AA, Nunemaker MS, Tiouririne M. Does Ondansetron Modify Sympathectomy Due to Subarachnoid Anesthesia?: Meta-analysis, Meta-regression, and Trial Sequential Analysis. Anesthesiology. 2016 Apr;124(4):846-69. doi: 10.1097/ALN.0000000000001039.

26 Faris PL, Kim SW, Meller WH, Goodale RL, Oakman SA, Hofbauer RD, Marshall AM, Daughters RS, Banerjee-Stevens D, Eckert ED, Hartman BK. Effect of decreasing afferent vagal activity with ondansetron on symptoms of bulimia nervosa: a randomised, double-blind trial. Lancet. 2000 Mar 4;355(9206):792-7.

27 Martinez JA, Rocha FS, Sobrani E, Galhardo FP, Terra Filho J. Effects of ondansetron on respiratory pattern and sensation of experimentally induced dyspnea. Sao Paulo Med J. 2002 Sep 2;120(5):141-5. 
28 Smoller JW, Pollack MH, Systrom D, Kradin RL Sertraline Effects on Dyspnea in Patients With Obstructive Airways Disease Psychosomatics 1998; 39:24-29

29 Miravitlles M, Molina J, Quintano JA, Campuzano A, Perez J, Roncero C Factors associated with depression and severe depression in patients with COPD Respiratory Medicine 2014;108, 1615e1625

30 Borges-Santos E, Takashi Wadaa J, Marques da Silva C, Silvaa RA, Stelmachb R, Carvalhoa CR, Lunardi AC Anxiety and depression are related to dyspnea and clinical control butnot with thoracoabdominal mechanics in patients with COPD Respiratory Physiology \& Neurobiology 2015; 210 1-6

31 Gordon GH, Michiels TM, Mahutte CK, Light RW Effect of Desipramine on Control of Ventilation and Depression Scores in Patients With Severe Chronic Obstructive Pulmonary Disease Psychiatry Research 1985: 15, 2532

32 Light RW, Merrill EJ, Despars J, Gordon GH, Mutalipassi LR Doxepin Treatment of Depressed Patients With Chronic Obstructive Pulmonary Disease Arch Intern Med. 1986; 146(7):1377-1380

33 Borson S, McDonald GJ, Gayle T, Deffebach M, Lakshminarayan S, VanTuinen C Improvement in Mood, Physical Symptoms, and Function With Nortriptyline for Depression in Patients With Chronic Obstructive Pulmonary Disease Psychosomatics May 1992; Volume 33, Issue 2, Pages 190-201

34 Papp LA, Weiss JR, Greenberg HE, Rifkin A, Scharf SM, Gorman JM, Klein DF Sertraline for chronic obstructive pulmonary disease and comorbid anxiety and mood disorders Am J Psychiatry. 1995 Oct; 152(10):1531.

35 Lacasse Y, Beaudoin L, Rousseau L, Maltais F. Randomised trial of paroxetine in endstage COPD. Monaldi Arch Chest Dis. 2004 JulSep;61(3):1407.

36 Eiser N , Harte R, Spiros K, Phillips C, Isaac MT Effect of treating depression on quality of life and exercise tolerance in severe COPD COPD. 2005 Jun;2(2):23341.

37 Usmani ZA, Carson KV, Cheng JN, Esterman AJ, Smith BJ Pharmacological interventions for the treatment of anxiety disorders in chronic obstructive pulmonary disease Cochrane Database of Systematic Reviews 2011, Issue 11. Art. No.: CD008483. DOI: 10.1002/14651858.CD008483.pub2.

38 Alexopoulos GS, Kiosses DN, Sirey JA, Kanellopoulos D, Seirup JK, Novitch RS, Ghosh S, Raueet PJ Untangling Therapeutic Ingredients of a Personalized Intervention for Patients with Depression and Severe COPD (PID-C) Am J Geriatr Psychiatry. 2014 November; 22(11): 1316-1324.

39 Momtaz OM, Rabei SM, Tawfike NR, Hasan AA Effect of treatment of depression and anxiety on physiological state of severe COPD patients Egyptian Journal of Chest Diseases and Tuberculosis 2015; 64, 29-34

40 Dale ET, Kirsh KL, Holtsclaw E, Donaghy K, Passik SD An Open-Label, Crossover Trial of Mirtazapine (15 and 30 mg) in Cancer Patients with Pain and Other Distressing Symptoms J Pain Symptom Manage 2002; 23: 442 - 447

41 Watts GJ, Clark K, Agar M, et al. Study protocol: a phase III randomised, double-blind, parallel arm, stratified, block randomised, placebo-controlled trial investigating the clinical effect and cost-effectiveness of sertraline for the palliative relief of breathlessness in people with chronic breathlessness. BMJ Open 2016;6:e013177. doi: 10.1136/bmjopen-2016- 013177

42 Church MK, Maurer M, Simons FER, Bindslev-Jensen C, van Cauwenberge P, Bousquet J, Holgate ST, Zuberbier T Risk of first-generation H1-antihistamines: a GA2LEN position paper Allergy 2010; 65: 459-466.

43 O’Neill PA, Morton PB, Stark RD Chlorpromazine-a specific effect on breathlessness? Br. J. Clin. Pharmac. 1985 , 19, 793-797 
44 Stark RD, Gambles SA, Lewis JA Methods to assess breathlessness in healthy subjects: a critical evaluation and application to analyse the acute effects of diazepam and promethazine on breathlessness induced by exercise or by exposure to raised levels of carbon dioxide Clinical Science 1981: 61, 429-439

45 Woodcock AA, Gross ER, Geddes DM Drug treatment of breathlessness: contrasting effects of diazepam and promethazine in pink puffers BMJ 1981; 283 343- 346

46 Rice KL, Kronenberg RS, Hedemark LL, Niewoehner DE Effects of chronic administration of codeine and promethazine on breathlessness and exercise tolerance in patients with chronic airflow obstruction British Journal of Diseases of the Chest 1987, 81, 287-292

47 Light RW, Stansbury DW, Webster JS Effect of $30 \mathrm{mg}$ of Morphine Alone or With Promethazine or Prochlorperazine on the Exercise Capacity of Patients With COPD Chest 1996; 109; 975-81

48 Whiting PF, Wolff RF, Deshpande S, Di Nisio M, Duffy S, Hernandez AV, Keurentjes JC, Lang S, Misso K, Ryder S, Schmidlkofer S, Westwood M, Kleijnen J Cannabinoids for Medical Use A Systematic Review and Meta-analysis JAMA. 2015; 313(24):2456-2473

49 Pickering EE, Semple SJ, Nazir MS, Murphy K, Snow TM, Cummin AR, Moosavi SH, Guz A, Holdcroft A Cannabinoid effects on ventilation and breathlessness: A pilot study of efficacy and safety Chronic Respiratory Disease 2011, 8(2) 109-118

50 Sudo T, Hayashi F, Nishino T Responses of Tracheobronchial Receptors to Inhaled Furosemide in Anesthetized Rats Am J Respir Crit Care Med 2000; Vol 162. pp 971-975

51 Hinckley JB Inhaled furosemide in the treatment of acute exacerbations of asthma Acad Emerg Med. 2000 Oct; $7(10): 1167$.

52 Ong KC, Kor AC, Chong WF, Earnest A, Wang YT Effects of Inhaled Furosemide on Exertional Dyspnea in Chronic Obstructive Pulmonary Disease Am J Respir Crit Care Med 2004; Vol 169. pp 1028-1033

53 Jensen D, Amjadi K, Harris-McAllister V, Webb KA, O'Donnell DE Mechanisms of dyspnoea relief and improved exercise endurance after furosemide inhalation in COPD Thorax 2008;63:606-613

54 Sheikh Motahar Vahedi H, Mahshidfar B, Rabiee H, Saadat S, Shokoohi H, Chardoli M, Rahimi-Movaghar V The Adjunctive Effect of Nebulized Furosemide in COPD Exacerbation: A Randomised Controlled Clinical Trial Respir Care 2013;58(11):1873-1877

55 Newton PJ, Davidson PM, Krum H, Ollerton R, Macdonald P The Acute Haemodynamic Effect of Nebulised Frusemide in Stable, Advanced Heart Failure Heart, Lung and Circulation 2012;21:260-266

56 Shimoyama N, Shimoyama M Nebulized Furosemide as a Novel Treatment for Dyspnea in Terminal Cancer Patients J Pain Symptom Manage 2002;23:73-76

57 Stone P, Rix E Nebulized Furosemide for Dyspnea in Terminal Cancer Patients J Pain Symptom Manage. 2002 Sep;24(3):274-5

58 Kohara H, Ueoka H, Aoe K, Maeda T, Takeyama H, Saito R, Shima Y, Uchitomi Y Effect of Nebulized Furosemide in Terminally III Cancer Patients with Dyspnea J Pain Symptom Manage 2003;26:962-967.

59 Wilcock A, Walton A, Manderson C, Feathers L, El Khoury B, Lewis M, Chauhan A, Howard P, Bell S, Frisby J, Tattersfield A. Randomised, placebo controlled trial of nebulised furosemide for breathlessness in patients with cancer Thorax. 2008 Oct;63(10):872-5. doi: 10.1136/thx.2007.091538. Epub 2008 Apr 11.

60 Nishino T, Tohru Ide, Sudo T, Sato J Inhaled Furosemide Greatly Alleviates the Sensation of Experimentally Induced Dyspnea Am J Respir Crit Care Med 2000; Vol 161. pp 1963-1967 
61 Minowa Y, Ide T, Nishino T Effects of Inhaled Furosemide on CO2 Ventilatory Responsiveness in Humans Pulmonary Pharmacology \& Therapeutics 2002; 15, 363-368

62 Moosavi SH, Binks AP, Lansinga RW, Topulos GP, Banzett RB, Schwartzstein RM Effect of inhaled furosemide on air hunger induced in healthy humans Respiratory Physiology \& Neurobiology 2007; 156; $1-8$

63 Laveneziana P, Galarducci A, Binazzi B, Stendardi L, Duranti R, Scano G Inhaled furosemide does not alleviate respiratory effort during flow-limited exercise in healthy subjects Pulmonary Pharmacology \& Therapeutics 2008;21; 196-200

64 Khan SY, O'Driscoll BR Is nebulized saline a placebo in COPD? BMC Pulmonary Medicine 2004, 4:9 doi:10.1186/1471-2466-4-9

65 Wang M, Li J, Li S, Xie Y. Effects of comprehensive therapy based on traditional Chinese medicine patterns on older patients with chronic obstructive pulmonary disease: a subgroup analysis from a four-center, randomised, controlled study. Front Med. 2014 Sep;8(3):368-75. doi: 10.1007/s11684-014-0360-0. Epub 2014 Sep 9.

66 Li SY, Li JS, Wang MH, Xie Y, Yu XQ, Sun ZK, Ma L, Zhang W, Zhang HL, Cao F, Pan YC. Effects of comprehensive therapy based on traditional Chinese medicine patterns in stable chronic obstructive pulmonary disease: a fourcenter, open-label, randomised, controlled study. BMC Complement Altern Med. 2012 Oct 29;12:197. doi: 10.1186/1472-6882-12-197.

67 Disler RT, Green A, Luckett T, Newton PJ, Inglis S, Currow DC, Davidson PM. Experience of advanced chronic obstructive pulmonary disease: metasynthesis of qualitative research. J Pain Symptom.Manage. 2014 Dec;48(6):118299.

68 Yu DS, Lee DT, Kwong AN, Thompson DR, Woo J. Living with chronic heart failure: a review of qualitative studies of older people. J Adv.Nurs. 2008 Mar;61(5):474-83.

69 Pesola GR, Ahsan H. Dyspnea as an independent predictor of mortality. Clin Respir J 2016; 10(2):142-152.

70 Jones PW, Adamek L, Nadeau G, Banik N. Comparisons of health status scores with MRC grades in COPD: implications for the GOLD 2011 classification. Eur. Respir J 2013 Sep;42(3):647-54

71 Johnson MJ, Bland JM, Gahbauer EA, Ekström M, Sinnarajah A, Gill TM et al. Breathlessness in the elderly during the last year of life sufficient to restrict activity, pattern and associated factors. Journal of the American Geriatric Society 2016; 64:73-80,

72 Niska R, Bhuiya F, XU J. National Hospital Ambulatory Medical Care Survey: 2007 emergency department summary. Natl Health Stat Report 2010;(26):1-31

73 Hardy J, Randall C, Pinkerton E, Flatley C, Gibbons K, Allan S. A randomised, double-blind controlled trial of intranasal midazolam for the palliation of dyspnoea in patients with life-limiting disease. Support Care Cancer 2016;24:3069.

74 Grove A, Lipworth BJ, Ingram CG, Clark RA, Dhillon DP A comparison of the effects of prednisolone and mianserin on ventilatory, exercise and psychometric parameters in patients with chronic obstructive pulmonary disease. Eur J Clin Pharmacol. 1995;48(1):13-8. 
Table 1: Benzodiazepines for breathlessness. Reproduced with permission of the European Respiratory Society ()

\begin{tabular}{|c|c|c|c|c|c|c|c|}
\hline $\begin{array}{l}\text { First } \\
\text { Author, } \\
\text { Year }\end{array}$ & Study design & Drug tested & $\begin{array}{l}\text { Patients } \\
\text { enrolled }\end{array}$ & $\begin{array}{l}\text { Breathlessness } \\
\text { measure }\end{array}$ & $\begin{array}{l}\text { Benefit perceived on acute- } \\
\text { induced Breathlessness (AIB) Vs } \\
\text { Chronic Breathlessness (CB) }\end{array}$ & $\begin{array}{l}\text { Statistically significant } \\
\text { benefit breathlessness }\end{array}$ & Notes \\
\hline $\begin{array}{l}\text { Simon } \\
2016^{20}\end{array}$ & $\begin{array}{l}\text { Cochrane } \\
\text { systematic } \\
\text { review }\end{array}$ & $\begin{array}{l}\text { alprazolam, diazepam, } \\
\text { midazolam, lorazepam, } \\
\text { clorazepate, temazepam }\end{array}$ & $\begin{array}{l}\text { COPD } \\
\text { Cancer }\end{array}$ & $\begin{array}{l}\text { VAS } \\
\text { Breathlessness } \\
\text { grade scale } \\
\text { Borg scale } \\
\text { Multidimensional } \\
\text { scales (SGRQ, CRQ) }\end{array}$ & $\mathrm{CB}$ & & Simon $2016^{20}$ \\
\hline $\begin{array}{l}\text { Clemens } \\
2011^{19}\end{array}$ & $\begin{array}{l}\text { Prospective, } \\
\text { non } \\
\text { randomised }\end{array}$ & $\begin{array}{l}\text { Oral lorazepam } 1 \mathrm{mg} \text { and } \\
\text { morphine as needed }\end{array}$ & $\begin{array}{l}26 \text { patients } \\
\text { admitted to a } \\
\text { palliative care } \\
\text { unit }\end{array}$ & $\begin{array}{l}\text { Numeric scale }(0- \\
10)\end{array}$ & $\mathrm{CB}$ & No & $\begin{array}{l}\text { Safety* of co- } \\
\text { administration }\end{array}$ \\
\hline $\begin{array}{l}\text { Allcroft } \\
2013^{16}\end{array}$ & $\begin{array}{l}\text { Open label } \\
\text { trial }\end{array}$ & $\begin{array}{l}\text { Oral clonazepam } 0.5 \mathrm{mg} \\
\text { nocte and morphine } \\
\text { extended release } 10 \mathrm{mg}\end{array}$ & $\begin{array}{l}11 \text { COPD with } \\
\mathrm{mMRC} \geq 2\end{array}$ & & & $\begin{array}{l}5 \text { patients reported } \\
\text { benefit }\end{array}$ & $\begin{array}{l}\text { Safety* of co- } \\
\text { administration }\end{array}$ \\
\hline $\begin{array}{l}\text { Hardy } \\
2016^{73}\end{array}$ & $\begin{array}{l}\text { Randomised, } \\
\text { double } \\
\text { blind, cross } \\
\text { over trial }\end{array}$ & Intranasal midazolam & $\begin{array}{l}62 \text { between } \\
\text { cancer, chronic } \\
\text { heart failure, } \\
\text { COPD }\end{array}$ & $\begin{array}{l}0-10 \text { breathlessness } \\
\text { score, HADS, } \\
\text { Cancer dyspnoea } \\
\text { scale }\end{array}$ & & & \\
\hline
\end{tabular}

* safety was defined as effect of benzodiazepines on breathing, ventilation and gas exchanges. COPD - chronic obstructive pulmonary disease; VAS - Visual

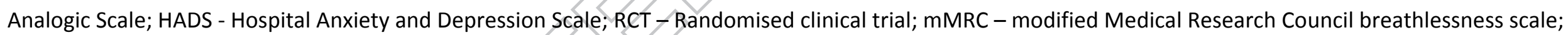
BDZ - benzodiazepines; SGRQ - St. George's Respiratory Questionnaire, CRQ - Chronic Respiratory Disease Questionnaire 
Table 2: Buspirone for breathlessness

\begin{tabular}{|c|c|c|c|c|c|c|}
\hline \multicolumn{7}{|l|}{ Buspirone } \\
\hline $\begin{array}{l}\text { First Author, } \\
\text { Year }\end{array}$ & $\begin{array}{l}\text { Type of } \\
\text { study }\end{array}$ & Drug tested & $\begin{array}{l}\text { Patients } \\
\text { enrolled }\end{array}$ & $\begin{array}{l}\text { Breathlessness } \\
\text { measure }\end{array}$ & $\begin{array}{l}\text { Statistically } \\
\text { significant } \\
\text { benefit } \\
\text { breathlessness }\end{array}$ & $\begin{array}{l}\text { Benefit perceived on } \\
\text { acute-induced } \\
\text { Breathlessness (AIB) } \\
\text { Vs Chronic } \\
\text { Breathlesness (CB) }\end{array}$ \\
\hline $\begin{array}{l}\text { Argyropoulou } \\
1993^{21}\end{array}$ & RCT & $\begin{array}{l}20 \mathrm{mg} \\
\text { Buspirone }\end{array}$ & 16 COPD & BORG & No & AIB \\
\hline Singh, $1993^{22}$ & RCT & $\begin{array}{l}30-60 \mathrm{mg} \\
\text { Buspirone }\end{array}$ & 11 COPD & BORG & No & $A I B$ and $C B$ \\
\hline $\begin{array}{l}\text { Peoples, } 2015 \\
23\end{array}$ & RCT & $\begin{array}{l}\text { 10-20 mg } \\
\text { Buspirone }\end{array}$ & $\begin{array}{l}432 \\
\text { Cancer }\end{array}$ & $\begin{array}{l}\text { OCD } \\
\text { STAI-S }\end{array}$ & No & $\mathrm{CB}$ \\
\hline
\end{tabular}

COPD - Chronic Obstructive pulmonary disease; OCD - Oxygen Cost diagram; STAI-S State-Trait Anxiety Inventory 
Table 3: Antidepressants for breathlessness

\begin{tabular}{|c|c|c|c|c|c|c|c|}
\hline \multicolumn{8}{|c|}{ Antidepressants, SSRI } \\
\hline $\begin{array}{l}\text { First Author, } \\
\text { Year }\end{array}$ & Type of study & Drug tested & $\begin{array}{l}\text { Patients } \\
\text { enrolled }\end{array}$ & $\begin{array}{l}\text { Breathlessness } \\
\text { measure }\end{array}$ & $\begin{array}{l}\text { Statistically } \\
\text { significant } \\
\text { benefit } \\
\text { breathlessness }\end{array}$ & Notes & $\begin{array}{l}\text { Benefit perceived on acute-induced } \\
\text { Breathlessness } \\
\text { (AIB) Vs Chronic Breathlessness (CB) }\end{array}$ \\
\hline $\begin{array}{l}\text { Gordon, } 1985 \\
31\end{array}$ & RCT & $\begin{array}{l}\text { 25-100 mg } \\
\text { despiramine }\end{array}$ & 13 COPD & n.a. & n.c. & $\begin{array}{l}\text { Poor } \\
\text { compliance, }\end{array}$ & \\
\hline Light, $1986^{32}$ & RCT & $\begin{array}{l}105-128 \mathrm{mg} \\
\text { doxepine }\end{array}$ & 12 COPD & n.a. & n.c. & $\begin{array}{l}\text { Improvemen } \\
\text { t in } 12 \mathrm{MWT}\end{array}$ & AIB \\
\hline $\begin{array}{l}\text { Borson, } 1992 \\
33\end{array}$ & RCT & nortriptyline & 30 COPD & n.a. & & $\begin{array}{l}\text { Improvemen } \\
\mathrm{t} \text { in } \\
\text { "respiratory } \\
\text { symptoms" }\end{array}$ & $\mathrm{CB}$ \\
\hline $\begin{array}{l}\text { Grove, } 1995 \\
74\end{array}$ & $\mathrm{RCT}$ & $\begin{array}{l}60-90 \mathrm{mg} \\
\text { mianserin }\end{array}$ & 12 COPD & n.a. & No & $\begin{array}{l}\text { The study } \\
\text { was } \\
\text { designed to } \\
\text { identify } \\
\text { difference } \\
\text { from oral } \\
\text { corticosteroi } \\
\text { ds }\end{array}$ & $A I B$ and $C B$ \\
\hline Dale $2002^{40}$ & $\begin{array}{l}\text { Open label, } \\
\text { cross-over RT }\end{array}$ & $\begin{array}{l}15-30 \mathrm{mg} \\
\text { mirtazapine }\end{array}$ & $\begin{array}{l}36 \\
\text { cancer }\end{array}$ & n.a. & n.c. & $\begin{array}{l}\text { Improvemen } \\
\text { t of cancer - } \\
\text { related }\end{array}$ & $\mathrm{CB}$ \\
\hline
\end{tabular}




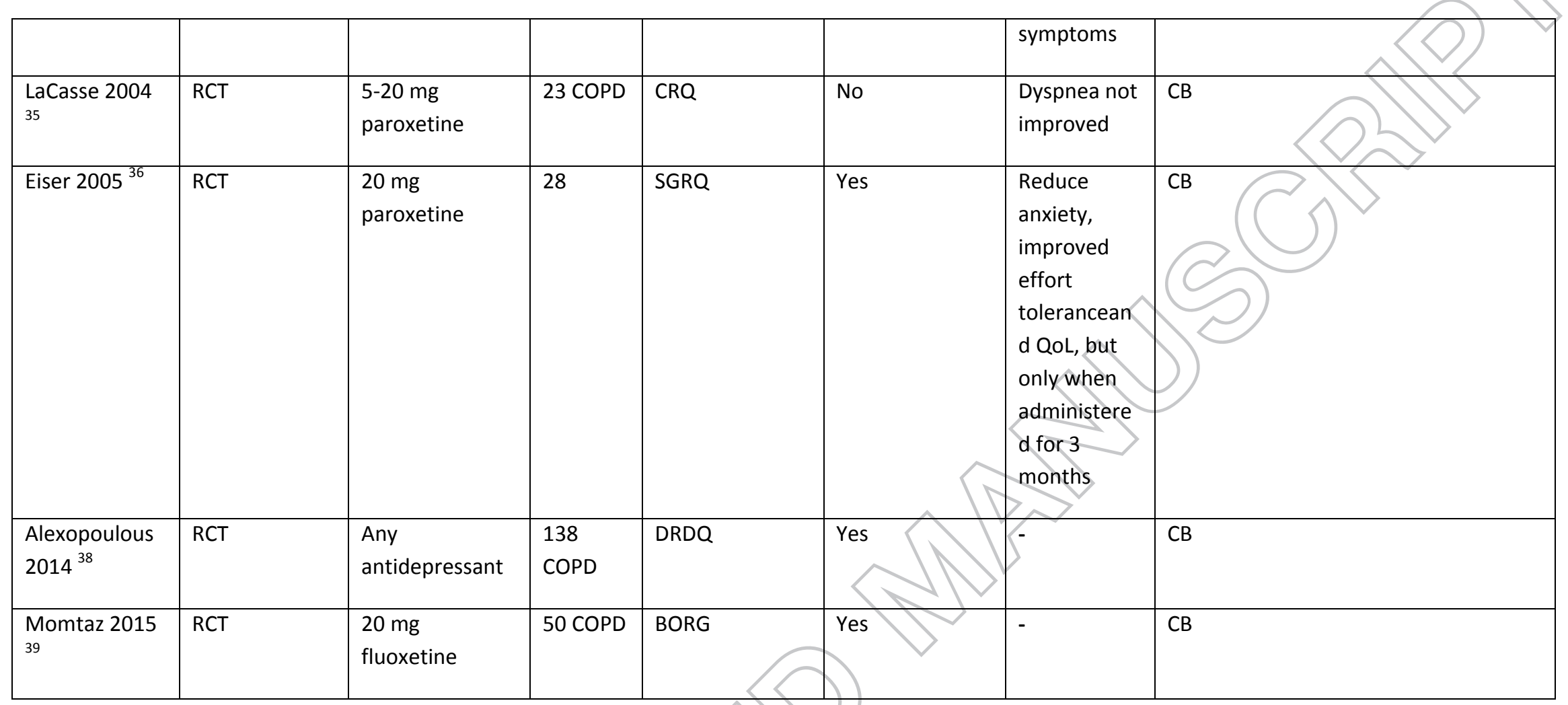

COPD - chronic obstructive pulmonary disease; n.c. - not conclusive; n.a. - not available; QoL - Quality of Life; CRQ - Chronic respiratory questionnaire; SGRQ St. George Respiratory questionnaire; DRDQ - Dyspnoea related disability questionnaire 
Table 4: antihistamines for breathlessness

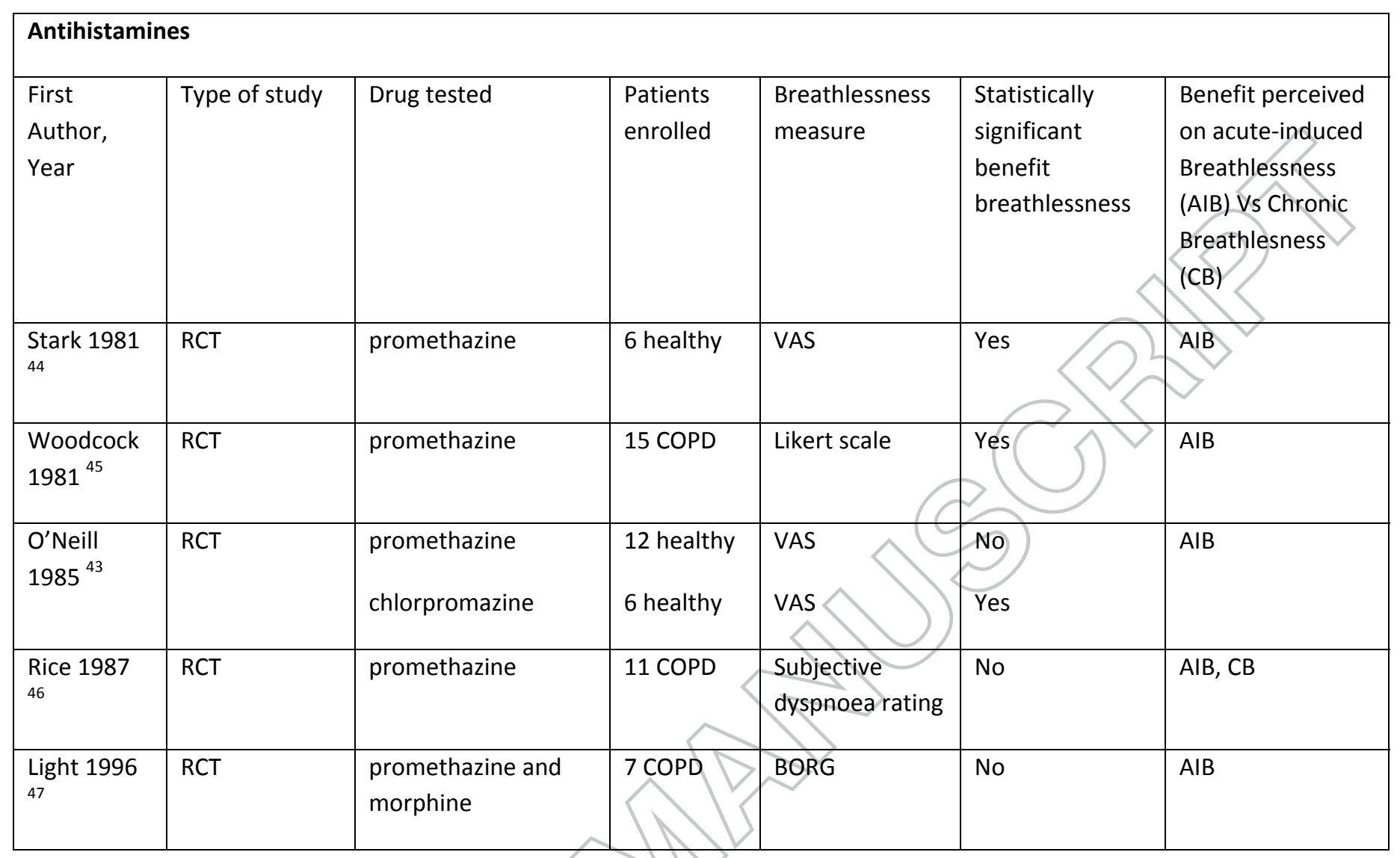

COPD - Chronic Obstructive pulmonary disease; VAS - Visual Analogic Scale 
Table 5: Nebulized Inhaled furosemide for breathlessness. Reproduced with permission of the European Respiratory Society ()

\begin{tabular}{|c|c|c|c|c|c|c|}
\hline \multicolumn{7}{|c|}{ Nebulized Inhaled Furosemide } \\
\hline $\begin{array}{l}\text { First Author, } \\
\text { Year }\end{array}$ & $\begin{array}{l}\text { Type of } \\
\text { study }\end{array}$ & $\begin{array}{l}\text { Drug } \\
\text { tested }\end{array}$ & $\begin{array}{l}\text { Patients } \\
\text { enrolled }\end{array}$ & $\begin{array}{l}\text { Breathlessness } \\
\text { measure }\end{array}$ & $\begin{array}{l}\text { Statistically } \\
\text { significant } \\
\text { benefit } \\
\text { breathlessness }\end{array}$ & $\begin{array}{l}\text { Benefit perceived on } \\
\text { acute-induced } \\
\text { Breathlessness (AIB) } \\
\text { Chronic Breathlesness } \\
\text { (CB) }\end{array}$ \\
\hline $\begin{array}{l}\text { Nishino } 2000 \\
60\end{array}$ & $\begin{array}{l}\text { RCT } \\
\text { crossover }\end{array}$ & $\begin{array}{l}\text { NIF } 40 \\
\mathrm{mg}\end{array}$ & 12 healthy & VAS & Yes & AIB \\
\hline $\begin{array}{l}\text { Minowa } 2002 \\
61\end{array}$ & RCT & $\begin{array}{l}\text { NIF } 40 \\
\mathrm{mg}\end{array}$ & 10 healthy & VAS & Yes & \\
\hline Stone $2002^{57}$ & $\begin{array}{l}\text { RCT } \\
\text { crossover }\end{array}$ & $\begin{array}{l}\text { NIF } 20 \\
\mathrm{mg}\end{array}$ & $\begin{array}{l}7 \text { lung cancer } \\
\text { terminal }\end{array}$ & VAS & No & \\
\hline Ong $2004^{52}$ & $\begin{array}{l}\text { RCT } \\
\text { crossover }\end{array}$ & $\begin{array}{l}\text { NIF } 40 \\
\mathrm{mg}\end{array}$ & 19 COPD & VAS & & AIB \\
\hline $\begin{array}{l}\text { Moosavi } 2007 \\
62\end{array}$ & $\begin{array}{l}\text { RCT } \\
\text { crossover }\end{array}$ & $\begin{array}{l}\text { NIF } 40 \\
\mathrm{mg}\end{array}$ & 10 healthy & & Yes & AIB \\
\hline $\begin{array}{l}\text { Laveneziana } \\
2008^{63}\end{array}$ & RCT & $\begin{array}{l}\text { NIF 40- } \\
80 \mathrm{mg}\end{array}$ & 9 healthy & & No & AIB \\
\hline Jensen $2008^{53}$ & $\begin{array}{l}\text { RCT } \\
\text { crossover }\end{array}$ & $\begin{array}{l}\text { NIF } 40 \\
\mathrm{mg}\end{array}$ & & BORG & Yes & AIB \\
\hline $\begin{array}{l}\text { Wilcock } 2008 \\
59\end{array}$ & RCT & & 15 cancer & BORG & No & AIB \\
\hline $\begin{array}{l}\text { Sheikh } \\
\text { Motahar } \\
\text { Vahedi } 2013 \\
54\end{array}$ & $\mathrm{RCT}$ & JIF 40 & $\begin{array}{l}100 \text { COPD } \\
\text { during } \\
\text { exacerbation }\end{array}$ & VAS & Yes & $\mathrm{CB}$ \\
\hline
\end{tabular}

